\title{
Distributions of total and active bacteria in biofilms lining tubes of the onuphid polychaete Diopatra cuprea
}

\author{
Tina M. Phillips, Charles R. Lovell* \\ Department of Biological Sciences, University of South Carolina, Columbia, South Carolina 29208, USA
}

\begin{abstract}
Infaunal burrows and tubes support elevated levels of microbial biomass and activities relative to the surrounding bulk sediments. The impacts of these structures on sediment biogeochemistry have been intensively studied, but very little is known about the microbiota or their spatial organization within these microenvironments. Distributions of bacterial cells and microcolonies and of potentially active bacterial cells in tubes of the onuphid polychaete Diopatra cuprea were determined using confocal scanning laser microscopy. Distributions were examined among different tubes, at different locations within a tube, and at different depths in the biofilms lining these tubes. The average quantity of cells across all tubes examined was $5.61 \times 10^{8} \mathrm{~cm}^{-3}$ and there was no trend in the distribution of cells along the length of the tube or with increasing depth in the biofilm. Cell size across all tubes collected in February 1997 averaged $0.085 \mu \mathrm{m}^{3}$ but varied seasonally. Mean cell size increased with increasing depth below the sediment surface of the tube site sampled, and decreased with increasing depth in the biofilm. Microcolonies were abundant and not confined to specific depths within the biofilm or locations within the tube. Potentially active cells were observed at all depths within the biofilm and at least $46 \%$ (mean $=68 \%$ ) of cells at any given site were potentially active. We hypothesize that the observed trends in cell distribution are responsive to tube irrigation by the host polychaete.
\end{abstract}

KEY WORDS: Microbial communities - Infaunal burrows - Spatial distributions - Confocal scanning laser microscopy

\section{INTRODUCTION}

Geochemical cycling of the major biogenic elements in nearshore marine sediments is primarily mediated by microorganisms. However, sediments are far from homogeneous and some specific microenvironments are particularly conducive to microbial activities. Chemocline environments, such as those found at the sediment-water interface, are well known to be sites of enhanced microbial activities (Novitsky 1983, Novitsky $\&$ Karl 1986). The classic model of these interface environments places aerobic metabolism at the sediment surface, followed by various anaerobic processes in deeper sediment layers (e.g. Fenchel 1969, Revsbech \& Jorgensen 1986, Aller 1988). However, surface sediments are subject to high levels of disturbance due to physical and biogenic reworking (Yingst \& Rhoads

- Addressee for correspondence. E-mail: lovell@biol.sc.edu
1980, Grant 1983). Sediment mixing can greatly stimulate some microbial activities by increasing the quantities of potential electron donors and acceptors below the sediment-water interface (Findlay \& White 1983, 1984, Krantzberg 1985, Findlay et al. 1990). Mixing also disrupts chemocline microbial communities and may significantly alter the interactions among various microbial functional groups and affect their potential for consortial metabolism (Paerl \& Pinckney 1996).

Macrofaunal burrows and tubes also provide significant chemocline niches for microbial growth. These structures are dug into anoxic subsurface sediments, irrigated with oxic seawater, and provide a large surface area for diffusive exchange (Aller \& Yingst 1978, Aller 1980, Boudreau \& Marinelli 1994), Irrigation of the burrow by the macrofaunal host organism results in the formation of radial chemoclines extending out from the burrow wall into the surrounding sediments (Aller \& Yingst 1978, Aller 1983, 1988, Boudreau \& 


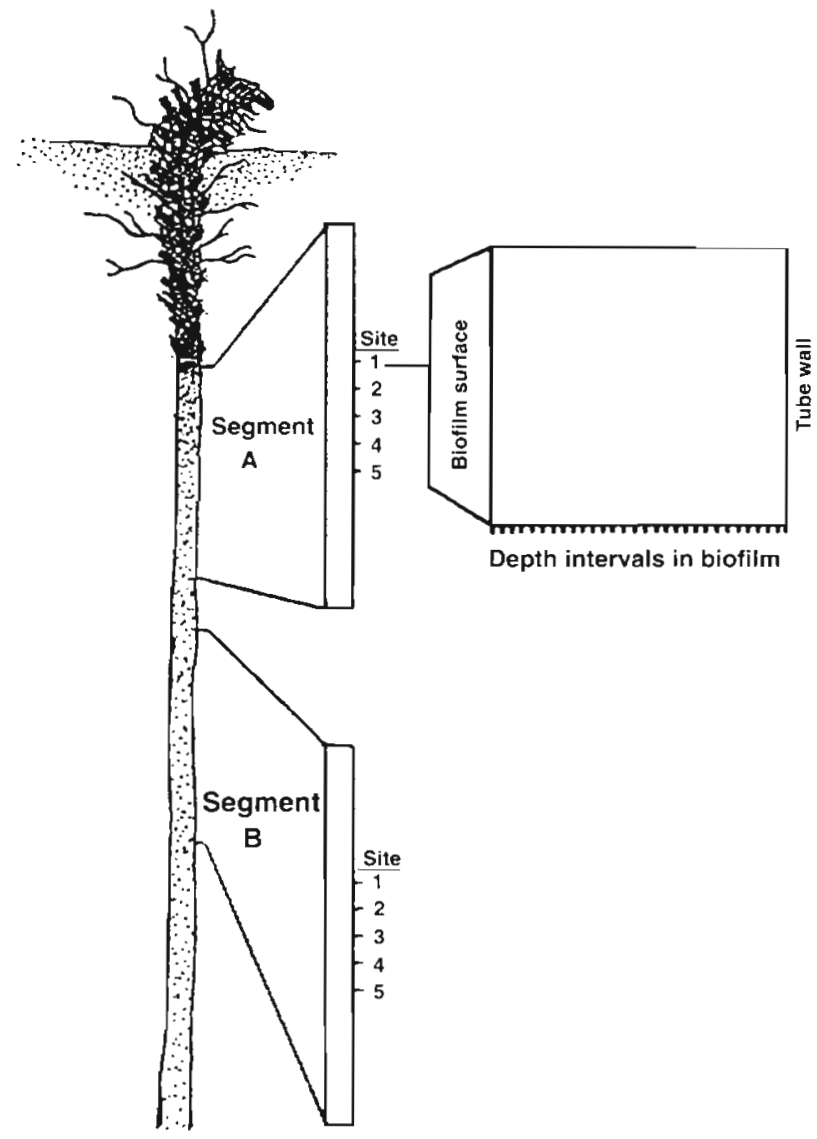

Fig. 1. Diopatra cuprea tube structure and the sampling procedure used to determine distributions of bacteria in $D$. cuprea tube lining biofilms. For each tube, two $8 \mathrm{~cm}$ segments of the unreinforced portion (Segments $A$ and B) were collected. In each of the segments, 5 sites ( 1 to 5) were examined. At each site, confocal images were collected at $1 \mu \mathrm{m}$ depth intervals from the surface of the biofilm to the tube wall

Marinelli 1994, Marinelli \& Boudreau 1996). These radial chemoclines provide overlapping gradients of potential electron donors and acceptors and are stable over time spans long enough for development of complex microbial communities (Aller \& Aller 1986, Marinelli et al. unpubl.). Macrofaunal burrows vary in their structural properties, ranging from loosely packed sediment/mucopolysaccharide aggregates, as seen in the burrows of the terebellid polychaete Amphitrite ornata, to well-defined polysaccharide and/or proteinaceous tubes, such as those of the chaetopterid polychaete Chaetopterus variopedatus and the onuphid polychaete Diopatra cuprea (Myers 1972, Aller \& Yingst 1978, Aller 1983). These structures promote development of microbial biofilms containing high levels of microbial biomass (Steward et al. 1996) and supporting intense geochemical cycling activities (Kristensen et al. 1985, 1991, Binnerup et al. 1992). Previous studies have shown that the microbiota of burrow lining biofilms differs from that of adjacent bulk sediments (Dobbs \& Guckert 1988, Steward et al. 1996) and that burrow and tube microbiota play important roles in the mineralization of organic compounds and the geochemical cycling of biogenic elements (e.g. Kristensen et al. 1985, 1991, Binnerup et al. 1992). The rates of geochemical processes within the burrow biofilm rely mainly on the constituents of the microbial community and their levels of activity. The latter are obviously highly dependent on the properties of the burrow (stability and permeability) and on the irrigation and exudation activities of the host animal. However, the distributions and potential for consortial interactions of these organisms are almost completely unknown and can best be studied using microscopic analysis.

Recent developments in microscopy, specifically confocal scanning laser microscopy, allow examination of bacterial biofilms in a non-invasive manner (Costerton et al. 1995). Studies to date have primarily examined biofilms grown on impermeable surfaces and little is known about natural biofilms growing on permeable surfaces and the microbiota inhabiting them. In this study, we examined distributions of total and active bacterial cells in biofilms lining the stable tube structure constructed by a ubiquitous infaunal polychaete, Diopatra cuprea. Several key features of the tube lining biofilm microbiota were revealed.

\section{CHARACTERISTICS OF THE DIOPATRA CUPREA TUBE}

The Diopatra cuprea tube is constructed from a mucous, sulphated polysaccharide, released from secreting glands, which hardens when it comes in contact with seawater (Myers 1972). Each tube displays 2 types of construction, reinforced and unreinforced (Fig. 1). The reinforced section rises from the sediment surface and can also extend down into shallow subsurface sediments. The length of this section is dependent on the degree of sediment disturbance, and the polychaete will extend it if the exposed portion becomes buried. The reinforced section of the tube is decorated with debris (small pebbles, shell fragments, and plant detritus) from the sediment surface. Occasionally, tubes will have 2 reinforced openings. The unreinforced section occurs below the sediment surface and is constructed as the worm moves vertically down through the sediments, creating a mucous sheath. The only foreign materials that may be attached to this portion of the tube are sediment particles in direct contact with the mucus when it is secreted. Additional layers of mucus are laid within the tube over time, so the thickness of the tube is directly proportional to its age. 


\section{MATERIALS AND METHODS}

Sampling site. Diopatra cuprea tubes were collected from an intertidal sandflat located at Oyster Landing, in the North Inlet saltmarsh $\left(33^{\circ} \mathrm{N}, 79^{\circ} \mathrm{W}\right)$, near Georgetown, South Carolina, USA. Oyster Landing is a small tidal tributary bordered by Spartina alterniflora marsh and oyster beds (Allen et al. 1992, Lovell \& Piceno 1994). The sandflat from which samples were collected is completely exposed during low tide and consists of quartz sand (median grain size of $376 \mu \mathrm{m}$ ) containing $0.22 \%$ silt and clay, and $0.83 \%$ organic matter, by dry weight (Lovell \& Piceno 1994).

Sample collection. All Diopatra cuprea tubes collected for this study were built by solitary individuals and had no tube branches. The amount of debris and firm attachment of the debris particles to the tube in the reinforced section made it impossible to mount samples of intact reinforced segments for microscopic examination or to remove the debris without disruption of the inner lining biofilm. Therefore, only the unreinforced sections of the tubes were analyzed in this study. The tube caps (apex of the reinforced section) were cut off at the sediment surface and the tubes exhumed until approximately 20 to $25 \mathrm{~cm}$ of the unreinforced portions were exposed. The length of the reinforced portion of each tube was measured and the approximate distance of the upper end of the unreinforced section from the sediment surface determined. From each tube a $20 \mathrm{~cm}$ sample (the deepest $2 \mathrm{~cm}$ of the reinforced and the first $18 \mathrm{~cm}$ of the unreinforced) was removed and further dissected into two $10 \mathrm{~cm}$ segments, designated Segments A and B (Fig. 1). These segments were selected to permit examination of the biofilm at close proximity to the tube inlet and at greater distance from it. Segment A consisted of $2 \mathrm{~cm}$ of the reinforced and the first $8 \mathrm{~cm}$ of the unreinforced. Segment B was the remaining $10 \mathrm{~cm}$ of the unreinforced tube sample. The $2 \mathrm{~cm}$ reinforced end of Segment $A$ and the first $2 \mathrm{~cm}$ of Segment $B$ permitted convenient handling of the tube samples without disruption of the biofilm in the remaining $8 \mathrm{~cm}$ segments.

Five Diopatra cuprea tubes were collected in February 1997 . The water and sediment temperatures at the time of collection were 20 and $19^{\circ} \mathrm{C}$, respectively. The samples were placed in $0.2 \mu \mathrm{m}$ filtered $2.5 \%$ formalin, transported to Columbia, SC, and stored at $4^{\circ} \mathrm{C}$ in the dark for no more than $1 \mathrm{wk}$ prior to analysis. Five additional D. cuprea tubes were collected in October 1997. The water temperature was $26^{\circ} \mathrm{C}$ and the sediment temperature was $25^{\circ} \mathrm{C}$ at that time. Tubes were handled as described above, but with the following modifications: (1) only Segment A for each tube was collected and (2) tube samples were not formalin fixed.
These samples were transported to Columbia, SC, and held in a recirculating sea water tank overnight.

Sample preparation and staining procedures. Each of the 10 tube segments from February 1997 was secured onto a glass microscope slide with rubber bands approximately $5 \mathrm{~cm}$ apart. The $2 \mathrm{~cm}$ ends designated for handling were then removed. The portion of the $8 \mathrm{~cm}$ segment between the 2 rubber bands was cut longitudinally and unrolled with the inner tube surface facing up. These samples were stained for enumeration and measurement of total cells and microcolonies.

SYTOX Green was selected as the primary fluorescent stain after substantial background fluorescence problems were encountered with acridine orange and fluorescein isothiocyanate. DAPI (4,6-diamidino-2phenylindole) was not tested since the excitation wavelength needed for this dye could not be obtained with our confocal microscope system. Fluorescence background from SYTOX Green, SYTO-9, and propidium iodide was quite low and permitted detailed assessment of cell distributions and appearances. Of a $12.5 \mu \mathrm{M}$ solution, $100 \mu \mathrm{l}$ of SYTOX Green (Molecular Probes, Inc., Eugene, OR) was added directly onto the inner surface and the sample incubated at room temperature in the dark for $5 \mathrm{~min}$. SYTOX Green penetrates only fixed cells (Roth et al. 1997), complexing with DNA. The stain-DNA complex fluoresces green when excited (excitation/emission: 504/523 nm). After incubation, a solution of 1,4-diazobicyclo[2,2,2]octane:glycerol (1:3) (Sigma, St. Louis, MO) was added to reduce photobleaching. A $22 \times 40 \mathrm{~mm}$ coverslip was taped down on top of the sample, holding it flat. The unfixed October 1997 tube segments were mounted as described above and stained for the enumeration of active and inactive cells (Lawrence et al. 1997). Metabolically active bacteria create a proton gradient across their plasma membrane through active transport of protons out of the cell. This electrochemical gradient, called the proton motive force, or membrane potential, provides a source of energy that can be used to drive ATP synthesis. SYTO-9 (excitation/emission: 488/509 nm; Molecular Probes, Inc.) only penetrates cells having membrane potential (Lebaron et al. 1998) and fluoresces green upon excitation. These cells are considered to be potentially active. Propidium iodide (excitation/emission: 535/617 nm; Molecular Probes, Inc.) only penetrates cells lacking membrane potential (Kaneshiro et al. 1993) and fluoresces red upon excitation. These cells are considered to be inactive. Of a $50 \mu \mathrm{M}$ SYTO-9, $149 \mu \mathrm{M}$ propidium iodide staining solution $100 \mu$ l was added to the samples, which were incubated and mounted as described above.

Confocal scanning laser microscopy. A Bio-Rad MRC-1000 Laser Scanning Confocal Microscope (Hercules, CA) equipped with a krypton/argon ion laser 
was used to produce fluorescence images of the tube lining biofilms. Confocal microscopy allows optical sectioning of the biofilm using an adjustable $\not$-axis stepping motor. At set successive intervals, the tunable laser (set to the appropriate excitation wavelength) is scanned over the sample and excites fluorescent dye complexes in a specific focal plane, allowing detection of stained cells at that specific depth $(z)$ in the biofilm. Data were collected at $1 \mu \mathrm{m}$ depth intervals in the biofilm until the tube wall was encountered, providing a complete $z$-profile of images from the top of the biofilm to the tube wall. The laser does not penetrate below the tube wall inner surface, and no fluorescence is observable below that depth (Fig. 1).

Two $z$-profiles were taken at each of 5 sites in each of the SYTOX Green stained tube segments. One profile of each pair was collected at $1000 \times$ magnification to allow determination of single cell distribution, the other at $400 \times$ magnification for determination of microcolony distribution. The first site in each tube segment was approximately $2.5 \mathrm{~cm}$ from the top of the segment (Site 1), with successive sites (Sites 2 to 5 ) at $5 \mathrm{~mm}$ intervals along the length of the segment. The dimensions of the fields of view were dependent on the magnification used (1000x: $114 \times 76 \mu \mathrm{m}, 400 \times$ : $288 \times$ $192 \mu \mathrm{m})$. Although data sets for single cell and microcolony distributions were collected at approximately the same sites, each is considered to be an independent sample due to microscale differences in biofilm surface texture and the difference in the areas analyzed using $1000 \times$ and $400 \times$ magification.

Profiles were also collected at 5 sites at $1000 \times$ magnification in each of the activity stained samples. A split spectral line (488 and $568 \mathrm{~nm}$ ) was used to excite both SYTO-9 and propidium iodide in order to visualize the potentially active (green) and non-active (red) cells simultaneously. Data were not collected on microcolonies in segments stained to determine potentially active bacteria due to the bright fluorescence of SYTO9 , which tended to overwhelm the fluorescence of propidium iodide in multicellular aggregates.

Data collection. Data collected at $1 \mu \mathrm{m}$ depth intervals in the biofilm to determine the distribution of single bacterial cells (February 1997 tubes) were compiled into a series of $5 \mu \mathrm{m}$ intervals (i.e. $0-5 \mu \mathrm{m}$, 6-10 $\mu \mathrm{m}, 11-15 \mu \mathrm{m}$, etc.) and the number of cells present in each interval counted. A total of 50 sites were examined for single cell distribution within the 5 tubes, but data for 1 site in 1 tube (Tube 1, Segment A, Site 1) were lost due to faulty digital storage. In order to avoid duplicate counting of cells that were at the border of 2 adjacent $5 \mu \mathrm{m}$ intervals, each interval image (except 0 to $5 \mathrm{\mu m}$ ) of a sequential pair of intervals was highlighted in a different color (red or green) and the 2 images were overlapped. Cells present in both inter- vals were indicated by yellow highlighting and were counted only in the first of the 2 intervals. Bacterial cells present in multicellular aggregates of more than 5 cells were not counted in these profiles. Lengths and widths of 10 arbitrarily selected cells were determined for each depth interval by optical magnification of collected images and measurement using calipers. If less than 10 cells were present in an interval, then each cell was measured. Mean cell size (average biovolume of a single cell) for each interval was calculated from the length and width measurements determined for single cells (Norland 1993). The total biovolume of single cells for each $5 \mu \mathrm{m}$ interval was calculated by multiplying the number of cells in that interval by the mean cell size for that interval.

Fifty sites were analyzed for the distribution of all types of multicellular aggregates. All multicellular aggregates, whether tightly packed and representing relatively high densities of cells, or loosely arranged, with relatively few cells, were designated as microcolonies. For each site, the $1 \mu \mathrm{m}$ images collected at $400 \times$ magnification were compiled in $3 \mu \mathrm{m}$ intervals. Some sites did not contain microcolonies. In some others, profiles were not completely perpendicular to the tube wall, prohibiting accurate measurement of depths in the biofilm. A total of 46 sites yielded useful data on microcolony distributions and sizes. Microcolony cross sectional area in each of the $3 \mu \mathrm{m}$ intervals was measured using MorphoSys (Meacham \& Duncan 1991). Biovolumes of the microcolonies were estimated by multiplying the microcolony cross sectional areas in the sequential $3 \mu \mathrm{m}$ intervals by the total depth of biofilm through which the colonies extended. No attempt was made to differentiate biovolume occupied by cells from that containing only exopolymeric materials. Due to microscale differences in the sites at which single cell and microcolony data were collected, total biovolume of bacteria, which would include all cells regardless of differing modes of growth, was not calculated.

Depth intervals $(5 \mu \mathrm{m})$ of each profile at the 5 sites in each of the tube segments stained to determine potentially active bacteria were compiled as described above and the number of potentially active cells and non-viable or inactive cells in each of the resulting $5 \mu \mathrm{m}$ depth intervals were counted. Duplicate counting of cells located at the border of 2 adjacent intervals was avoided by aligning the 2 intervals side by side and comparing cell placement in the field of view. One arbitrarily selected profile from each activity stained tube segment was used for determination of average sizes of active and inactive cells (Tube 1, Site 1 ; Tube 2, Site 1; Tube 3, Site 5; Tube 4, Site 2; Tube 5, Site 3) as described above. Lengths and widths of all potentially active and inactive cells were measured and mean cell 
sizes calculated for each of the $5 \mu \mathrm{m}$ intervals in these profiles as described above.

Statistical analyses. The SAS System for Windows (version 6.12, SAS Institute, Inc., Cary, NC, USA) was used to perform all statistical analyses. Nested analysis of variance was used to determine significant differences in cell numbers, cell size, and biovolume among tubes, among segments, and among sites for data collected from Diopatra cuprea tubes stained with SYTOX Green. Regression analysis was used to evaluate relationships between cell numbers, mean cell size, or biovolume, and depth in the biofilm for all sets of tube segments. Cell size variance was modeled using the gamma distribution with generalized linear model, using generalized estimating equations to accommodate the nested design. All data were tested for normality and statistical tests were performed using a significance level of $\alpha=0.05$.

\section{RESULTS AND DISCUSSION}

\section{Bacterial single cell distributions and sizes}

Confocal microscopy revealed that the tubes of Diopatra cuprea supported substantial biofilms containing abundant bacteria occurring as single cells and in microcolonial formations. The thickness of $D$. cuprea tube biofilm ranged from 30 to $110 \mu \mathrm{m}$, with an average thickness of $60 \mu \mathrm{m}$. The quantity of individual bacterial cells at a given site ranged from 1.38 $\times 10^{8}$ to $1.33 \times 10^{9}$ cells $\mathrm{cm}^{-3}$ (mean $=5.61 \times 10^{8}$ cells $\mathrm{cm}^{-3}$, Fig. 2A). Nested analysis of variance revealed that cell numbers differed significantly from site to site (df 8,$31 ; F=3.00 ; p \leq 0.02$ ), but not among tubes (df $4.4 ; F=3.14 ; \mathrm{p} \geq 0.14$ ) or between Segments $A$ and $\mathrm{B}$ (df 4,$8 ; F=1.01 ; \mathrm{p} \geq 0.45$ ). There was no consistent pattern of cell distribution within the tube lining biofilm (Fig. 3). Twenty-five of the 49 sites had highest cell numbers within $10 \mu \mathrm{m}$ of the biofilm surface. Twenty-three had additional subsurface peaks in cell numbers. Cell numbers decreased significantly (regression analysis, $p<0.05$ in all cases) with increasing depth in the biofilm at 28 of the 49 sites, but the remaining sites showed no significant changes with depth

Unlike cell numbers, mean bacterial cell sizes did change with depth below the sediment surface. Cell sizes at different sites in the tube segments ranged from 0.032 to $0.285 \mu^{3}$ (grand average: $0.085 \mu^{3}$, Fig. 2B). Nested analysis of variance revealed significant differences in mean cell size between Segments $A$ and $B$ (df 4,$8 ; F=4.93 ; \mathrm{p} \leq 0.03$ ), with cells in Segment $B$ averaging larger than those in Segment A. No significant differences in mean cell size were found
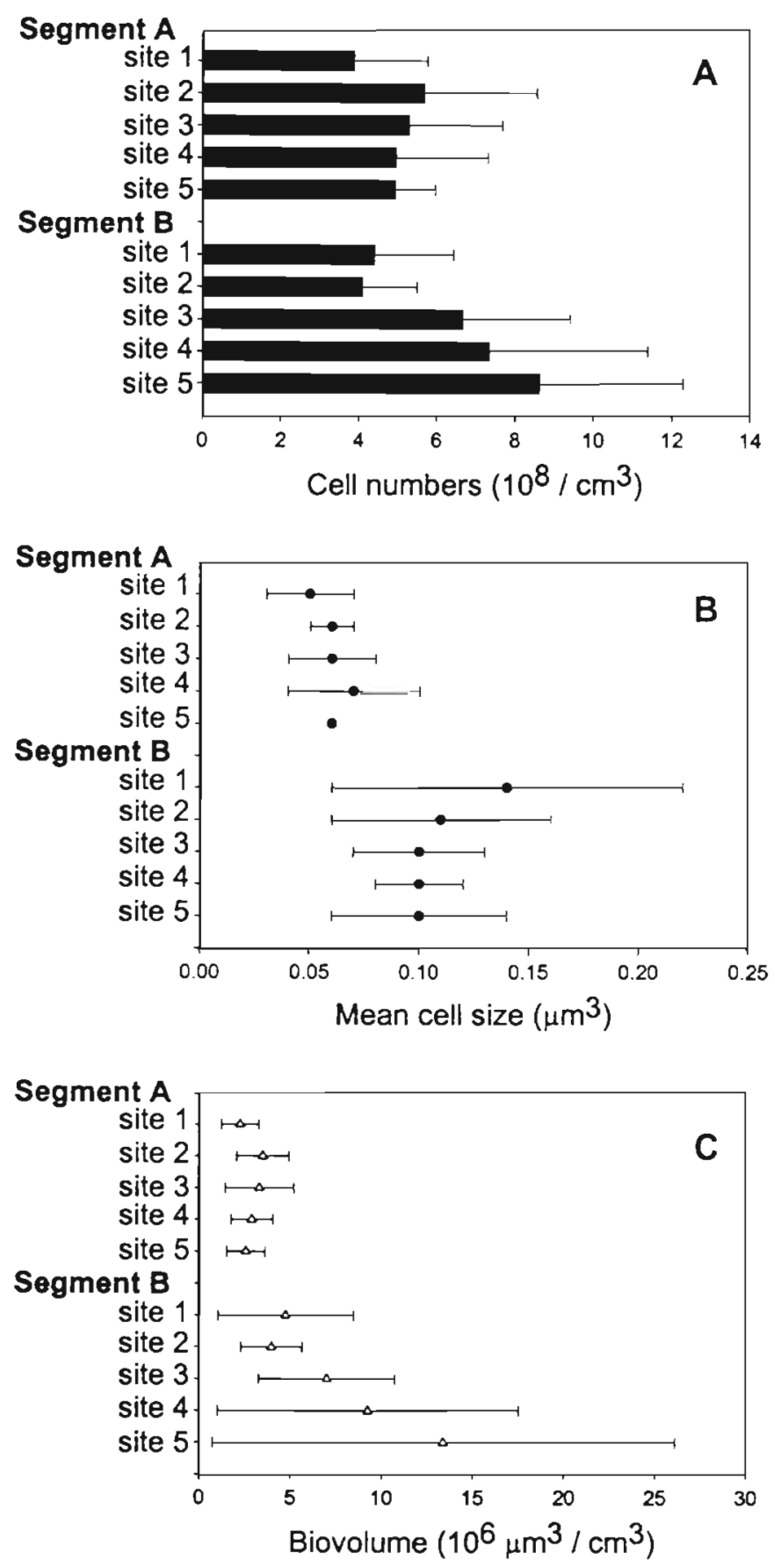

Fig. 2. (A) Cells per $\mathrm{cm}^{3}$, (B) mean cell size, and (C) biovolume (cell numbers multiplied by mean cell size at each site) in Diopatra cuprea tube lining biofilms. Mean ( \pm SD) is shown for each of the 5 sites within each segment across all 5 tubes ( $n=5$ except for Segment A, Site 1 , where $n=4$ )

among tubes (df 4,$4 ; F=0.60 ; p \geq 0.68$ ) or sites (df 8,31; $F=1.19 ; p \geq 0.3$ ). Based on Diopatra cuprea behavior and bacterial stress responses, this trend is quite different from what would be expected. $D$. cuprea spends most of its time in the upper portion of the tube near 
Mean cell size $\left(\mu \mathrm{m}^{3}\right)$
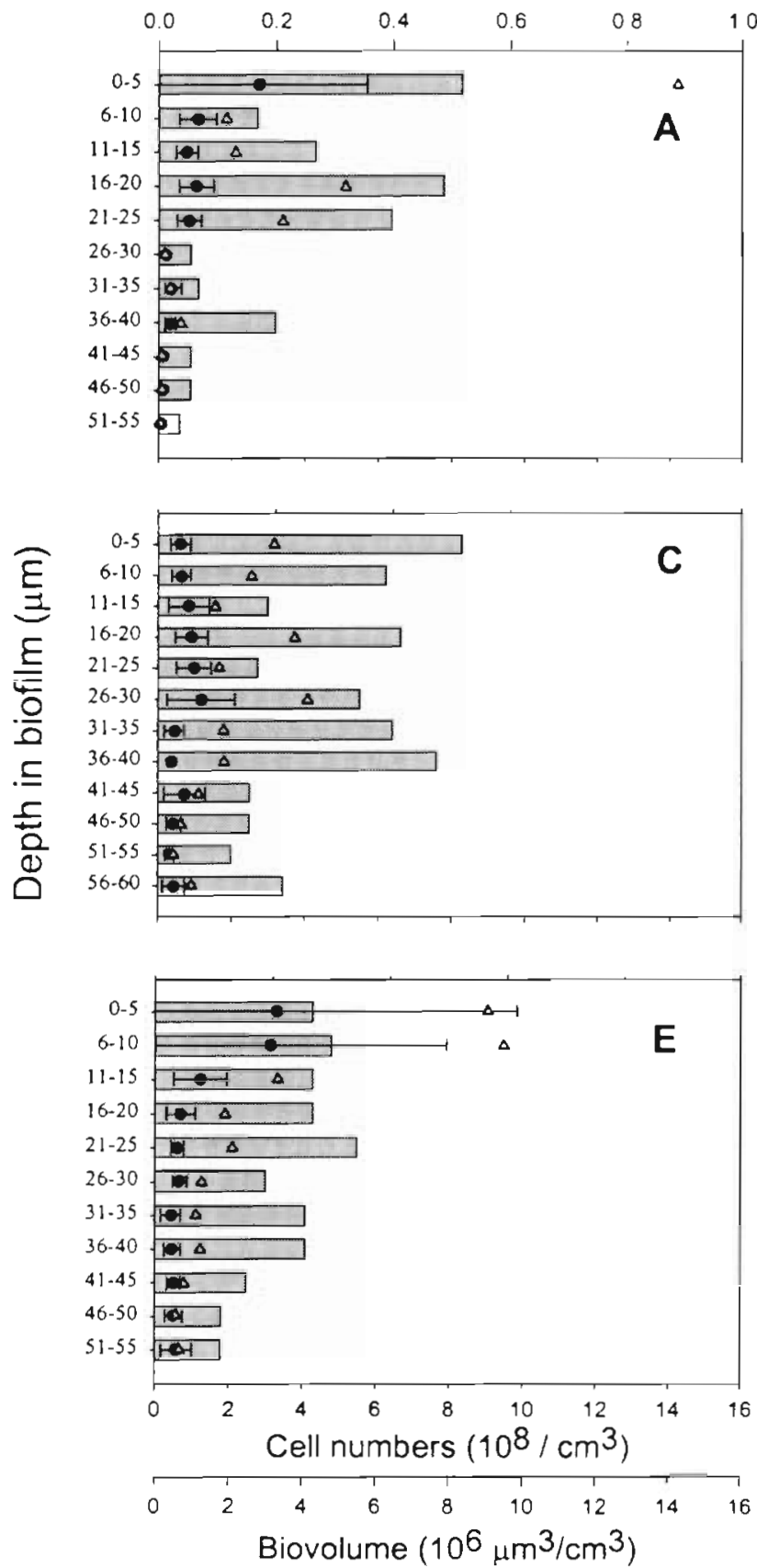

the sediment surface and irrigation of the tube is frequent but not continuous. At the depths of the tube sites examined ( 10 to $36 \mathrm{~cm}$ below the sediment surface), the only oxygen available to the microbiota and a substantial portion of the nutrient inputs are provided by host irrigation. Consequently, sites at greater depths should experience greater oxygen and/or nutrient limitation due to the lesser impact of irrigation. Bacteria in nature that are severely nutrient limited are typically smaller than their more resource-sufficient
Mean cell size $\left(\mu \mathrm{m}^{3}\right)$
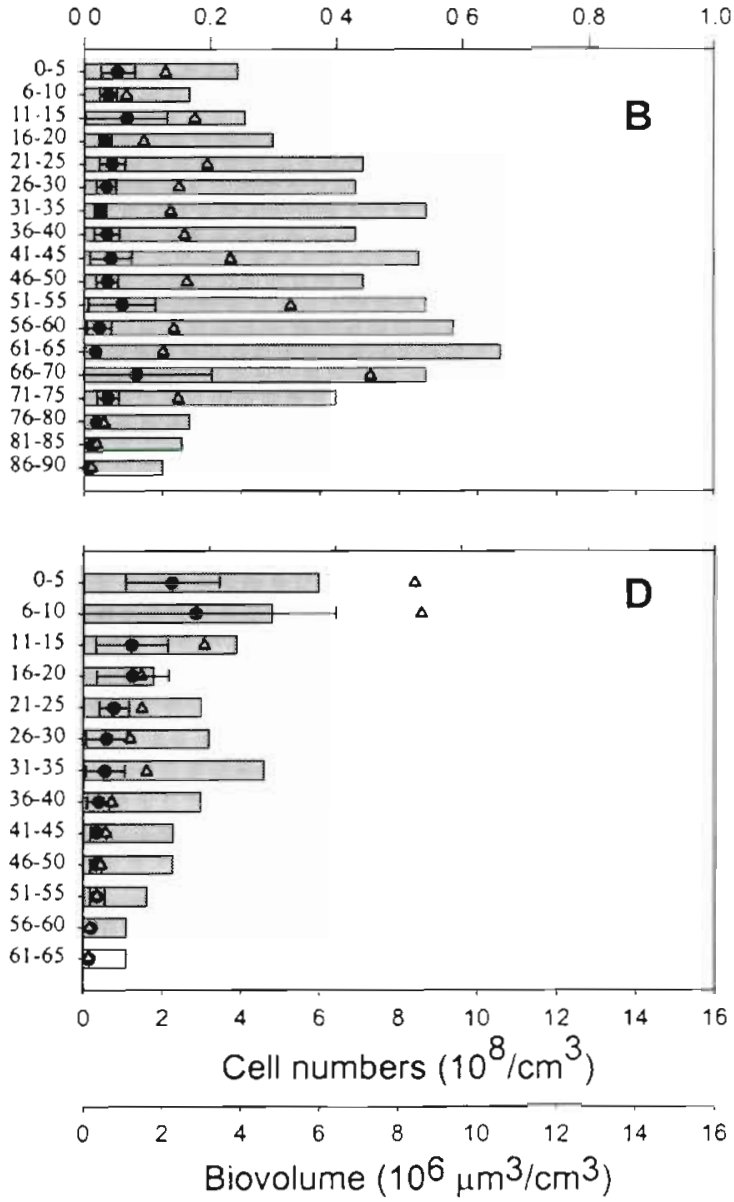

Fig. 3. Distribution of cell numbers (bars), mean cell size $( \pm \mathrm{SD}, \mathrm{n}=1$ to 10$)(\bullet)$ and biovolume (cell numbers multiplied by mean cell size per $5 \mu \mathrm{m}$ interval) ( $\Delta$ ) with increasing depth into Diopatra cuprea tube lining biofilm for Sites 1 (A), 2 (B), 3 (C), 4 (D) and 5 (E) in Segment A of Tube 2

counterparts (Kjelleberg et al. 1987, Chesbro et al. 1990, Kaprelyants et al. 1993). If cells located deeper in the tube were oxygen and/or nutrient limited they should have been smaller than those at shallower depths, but that was not the case.

There was also a clear pattern in the distribution of bacterial cell size with depth in the burrow lining biofilm (Fig. 3). The largest mean cell sizes were found in intervals within $10 \mu \mathrm{m}$ of the biofilm surface at 32 of the 49 sites. Nineteen sites had subsurface peaks in cell size. 
Almost all sites (42 out of 49) showed significant decreases in mean cell size (regression analysis, $p<0.05$ in all cases) and of variance in cell size $(E=-0.0005 ; \mathrm{SE}=$ $0.0002 ; Z=-1.906 ; \mathrm{p} \leq 0.01$ ) with increasing depth into the biofilm. This trend may have been due to nutrient or oxygen limitation at the base of the biofilm.

The biovolume of single cells at a given site, a function of the grand average of cell sizes (i.e. average of mean cell sizes for all intervals at that site) and cell

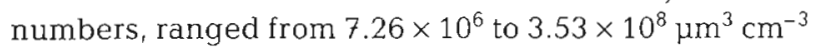
(mean $=5.33 \times 10^{7} \mathrm{~mm}^{3} \mathrm{~cm}^{-3}$, Fig. $2 \mathrm{C}$ ). Nested analysis of variance showed that biovolume differed significantly among sites (df 8,$31 ; F=2.39 ; \mathrm{p} \leq 0.04$ ) but not between Segments $A$ and $B$ (df 4,$8 ; F=2.06 ; p \geq 0.17$ ) or among tubes (df 4,$4 ; F=0.95 ; \mathrm{p} \geq 0.51$ ). The highest biovolumes in 24 of 49 sites were within $10 \mu \mathrm{m}$ of the biofilm surface while 12 sites had subsurface biovolume peaks. There was a significant relationship between biovolume and depth in the biofilm at 34 of 49 sites, and biovolume decreased with increasing depth in the biofilm in at least half of the sites in each tube (Fig. 3).

\section{Microcolony distribution}

Microcolonies covered a broad range of sizes and were found throughout the length of the Diopatra cuprea tube and at all depths within the biofilm. The number of microcolonies at a given site ranged from 1 to 31 (mean $=5$ ) and these formations were located at various depths throughout the biofilm. Microcolony biovolume ranged from $16 \mu \mathrm{m}^{3}$ to $2.5 \times 10^{5} \mu \mathrm{m}^{3}$ (mean $=1.28 \times 10^{4} \mu^{3}{ }^{3}$ ). Nested analysis of variance revealed that the microcolony biovolumes did not differ significantly among sites (df 8,$28 ; F=1.55 ; \mathrm{p} \geq$ 0.18 ), between Segments $A$ and $B(d f 4,8 ; F=1.83 ; \mathrm{p} \geq$

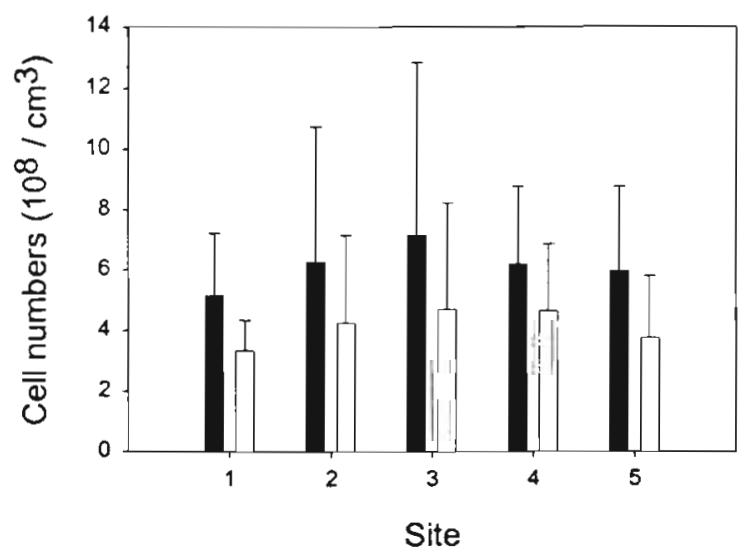

Fig. 4. Total (black bars) and potentially active (open bars) cells per $\mathrm{cm}^{3}$ for each site in Segment A of Diopatra cuprea tube lining biofilms. Mean (+ SD) is shown for each site for 5 tubes
0.21 ), or among tubes (df 4,$4 ; F=1.96 ; \mathrm{p} \geq 0.26$ ). The structures of microcolonies varied from very tightly organized formations to loose aggregations of cells and exopolymers. The potential of these structures to facilitate interactions among different bacterial species (Paerl \& Pinckney 1996) is clear and their formation may be very important to the overall activities of the biofilm.

\section{Potentially active versus inactive cells}

Diopatra cuprea tubes were also stained to permit determination of the proportions of cells that were intact and potentially active versus those lacking membrane potential and thus presumably inactive (Lawrence et al. 1997). The total number of cells per site in segments stained to determine bacterial activity ranged from $2.62 \times 10^{8}$ to $1.71 \times 10^{9} \mathrm{cells} \mathrm{cm}^{-3}$ (mean = $6.11 \times 10^{8} \mathrm{~cm}^{-3}$ ). The proportion of total cells that were potentially active was quite high (Fig. 4), ranging from 0.46 to 0.85 (mean $=0.68$ ), and did not significantly differ among sites (df 4,$16 ; F=1.33 ; \mathrm{p} \geq 0.29$ ). Potentially active cells were observed at all depths within the biofilm (Fig. 5) and the proportion of cells that were potentially active was similar at all depths at 19 of the 25 sites. The proportion of active cells increased with increasing depth in the biofilm at 3 sites and decreased with increasing depth at the remaining 3 sites $(\mathrm{p}<0.05$ in all cases). The abundance of potentially active cells was not surprising since previous studies have shown

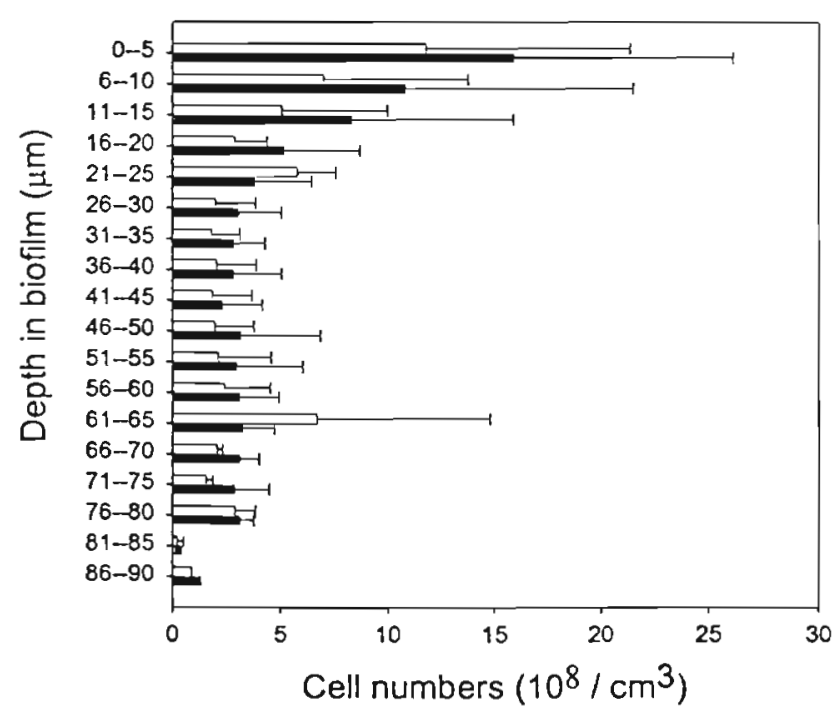

Fig. 5. Total (black bars) and potentially active (open bars) cells per $\mathrm{cm}^{3}$ in Segment A of Diopatra cuprea tube lining biofilms. Mean ( $+\mathrm{SD})$ at each depth in the biofilm, across all sites, is shown. The number of samples varies from 1 to 25 at different depths in the biofilm due to differences in biofilm thickness at different sites 


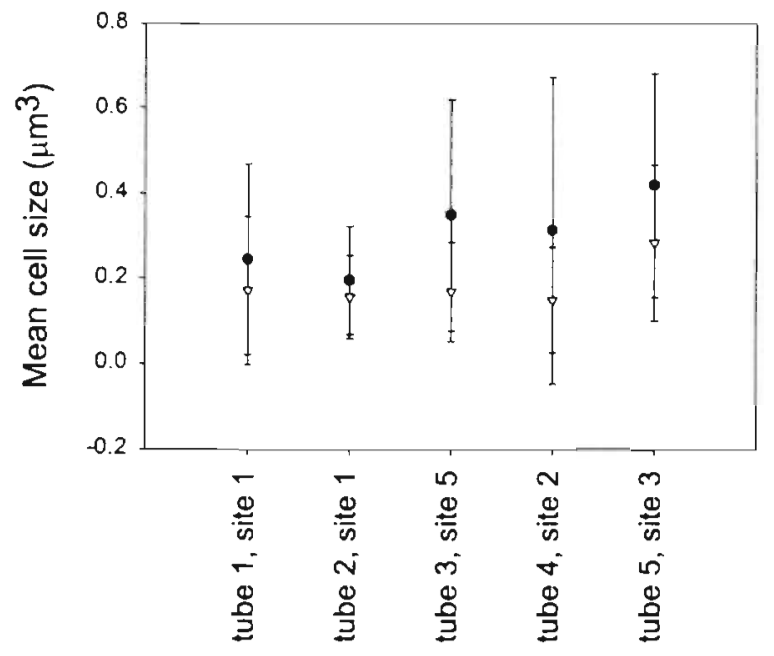

Fig. 6. Potentially active $(\bullet)$ and inactive $(\nabla)$ cell sizes in Diopatra cuprea tube lining biofilms. Mean $( \pm \mathrm{SD})$ is shown for 1 site in each tube. Sample size (n) for potentially active cells ranges from 43 to 94 ; sample size (n) for inactive cells ranges from 33 to 79

that infaunal burrows are sites of intense microbial activity and contain substantial amounts of viable microbial biomass (Aller \& Yingst 1978, Aller 1980, Dobbs \& Guckert 1988, Steward et al. 1996). What was surprising was that cells at depth in the biofilm and at sites far below the sediment surface appeared to be as capable of activity as those near the biofilm surface and at sites near the sediment surface.

Sizes of potentially active and inactive cells were also measured at 1 site in each of the 5 tube segments. The average size of potentially active cells ranged from 0.19 to $0.42 \mu \mathrm{m}^{3}$ (grand mean $=0.3 \mu \mathrm{m}^{3}$ ) and was sig-

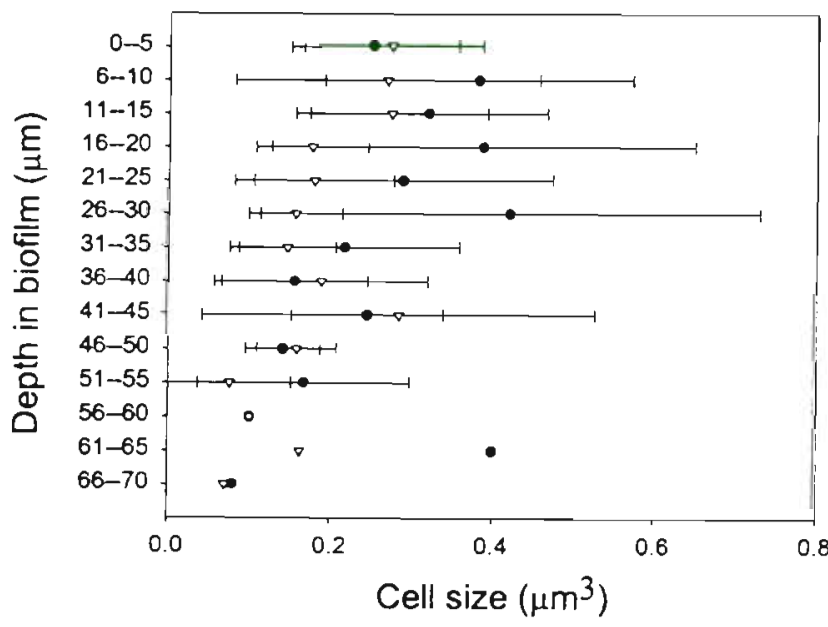

Fig. 7. Mean potentially active $(\bullet)$ and inactive $(\nabla)$ cell sizes in Diopatra cuprea tube lining biofilms. Means $( \pm \mathrm{SD})$ at each depth in the biofilm, across all 5 sites, is shown. The number of samples at a given depth in the biofilm varies due to differ-ences in biofilm thickness ( $n=1$ to 5 ) nificantly larger than that of inactive cells (range: 0.15

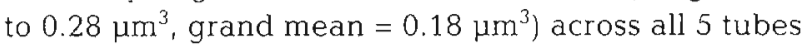
(df $A_{i} ; T=4.37 ; \mathrm{p} \leq 0.01$ ) (Fig. 6). There was no general pattern in the distribution of potentially active or inactive mean cell sizes in relation to the depth in the biofilm (Fig. 7). The variance of potentially active cell size significantly decreased with increasing depth in the biofilm $(E=-0.0017$; $\mathrm{SE}=0.0006 ; Z=-2.945 ; \mathrm{p} \leq$ $0.01)$ while the variance of inactive cell size increased with depth $(E=0.0005 ; \mathrm{SE}=0.0004 ; Z=-1.416 ; \mathrm{p} \leq$ $0.01)$. The observed size differences between potentially active and inactive cells were consistent with reports of stressed or starved cells being on average smaller than actively growing cells of the same species (reviewed in Kjelleberg et al. 1987),

\section{Seasonal differences in cell parameters}

Comparisons were also made between mean cell numbers and sizes in Segment $A$ of tubes collected in October and February 1997 There was no significant difference in the mean number of cells per tube between the 2 sets ( df 1,$8 ; F=0.31 ; p \geq 0.50$ ). However, there was a difference in mean cell size. Mean cell sizes in tubes collected in October 1997 for activity staining were significantly larger, 0.18 to $0.38 \mathrm{\mu m}^{3}$, than those in tubes collected in February 1997, 0.058 to $0.09 \mu^{3}$ (df 1,$8 ; F=0.093 ; \mathrm{p} \leq 0.01$ ). One clear difference between the February and October samples was formaldehyde fixation of the February samples. Turley \& Hughes (1992) reported about $10 \%$ reduction in cell size (estimated from digitized cell images) in fixed samples stored for 39 to $53 \mathrm{~d}$, but provided no data for shorter storage times. Troussellier et al. (1995), using flow cytometric light scatter techniques, found no measurable changes in cell structure or morphology in samples fixed for a much shorter time period ( $24 \mathrm{~h})$. The short times ( $\leq 1 \mathrm{wk}$ ) our fixed samples were stored prior to analysis seem unlikely to produce significant cell shrinkage. Even shrinkage comparable to that reported by Turley \& Hughes (1992) could not account for the almost 3-fold difference in mean cell size we observed between the February and October samples. A more likely explanation for the difference in cell size can be based on the biology of Diopatra cuprea. The water temperature in October was warmer than in February and the polychaetes likely irrigated more actively in October (e.g. Mangum \& Sassaman 1969). More frequent irrigation during the warmer period would increase the availability of oxygen and nutrients. Warmer water temperature would also have a positive effect on the bacterial communities, resulting in faster growth and an increase in mean cell size. 
The differences in the relationship of mean cell size and depth in the biofilm between the 2 collection dates could also be a result of irrigation intensity and frequency. In February, cells became smaller and more uniform in size with increasing depth in the biofilm. This trend was not observed in tubes collected in October and could be due to oxygen and nutrient limitation of microorganisms located deeper in the biofilm.

\section{Additional observations}

Recent studies of many laboratory-cultivated biofilms have revealed channels of low-density-exopolymer throughout the material (e.g. Stewart et al. 1993, Stoodley et al. 1994, Wolfaardt et al. 1994). These channels are thought to be essential for nutrient transport to organisms deep within the biofilm (Lawrence et al. 1994, Costerton et al. 1995) and can be revealed through staining with fluorescently tagged lectins, which bind specifically to the biofilm polysaccharides. Staining with fluorescein isothiocyanate-labeled concanavalin A (Sigma), which selectively binds $\alpha$-mannopyranosyl and $\alpha$-glucopyranosyl residues in polysaccharides, revealed no channels within the Diopatra cuprea tube biofilm (data not shown). D. cuprea deposits many layers of mucus over time and cells that are on the surface of the tube lining eventually become embedded within the tube matrix. Any channels that might arise could be filled with worm mucus on the next cycle of polymer deposition. However, channels may not be required for active microbial metabolism throughout the tube-lining biofilm. Aller (1983) suggested that the tube linings of macro-infaunal organisms could be considered to be highly hydrated porous membranes (Aller 1983). Diffusion of small molecules through the tube (including the biofilm) would not be hindered by such materials and thus activity of bacteria at depth in the biofilm could be supported.

The Diopatra cuprea tube supports an abundant and varied microbial community that contains an unusually high proportion of potentially active cells. These findings are consistent with the high levels of microbial biomass and activity reported for various infaunal burrows and tubes. The trends observed in cell size distributions are very intriguing in that they may reflect the nutritional and/or stress regimes the organisms experience in response to irrigation of the tube by $D$. cuprea. Manipulative experiments exploring the impact of tube irrigation on biofilm microbiota and molecular biological characterization of these organisms are ongoing.
Acknowledgements. We gratefully acknowledge John Kaigler for drawing Fig. 1, Holms Finch and Sarah Woodin for their assistance with statistical analysis of data, Sarah Woodin for information on the lifestyle and habits of Diopatra cuprea. and Courtney Richmond for her help with MorphoSys. We would also like to thank Bob Price (IMAF, Univ. South Carolina Medical School) for his guidance in the use of the confocal microscope. This research was supported by grant number No00149610403 from the United States Office of Naval Research to C.R.L.

\section{LITERATURE CITED}

Allen DM, Service SK, Ogburn-Matthews MV (1992) Factors influencing the collection efficiency of estuarine fishes. Trans Am Fish Soc 121:234-244

Aller JY, Aller RC (1986) Evidence for localized enhancement of biological activity associated with tube and burrow structures in deep-sea sediments at the HEBBLE site, western North Atlantic. Deep-Sea Res 33:755-790

Aller RC (1980) Quantifying solute distributions in the bioturbated zone of marine sediments by defining an average microenvironment. Geochim Cosmochim Acta 44: $1955-1965$

Aller RC (1983) The importance of the diffusive permeability of animal burrow linings in determining marine sediment chemistry. J Mar Res 41:299-322

Aller RC (1988) Benthic fauna and biogeochemical processes in marine sediments: the role of burrow structures. In: Blackburn TH, Sorensen J (eds) Nitrogen cycling in coastal marine environments. Wiley, Chichester, p 301-338

Aller RC, Yingst JY (1978) Biogeochemistry of tube dwellings: a study of the sedentary polychaete Amphitrite ornata (Leidy). J Mar Res 36:201-254

Binnerup SJ, Jensen K, Revsbech NP, Jensen MH, Sorensen J (1992) Denitrification, dissimilatory reduction of nitrate to ammonium, and nitrification in a bioturbated estuarine sediment as measured with ${ }^{15} \mathrm{~N}$ and microsensor techniques. Appl Environ Microbiol 58:303-313

Boudreau BP, Marinelli RL (1994) A modelling study of discontinuous biological irrigation. J Mar Res 52:947-968

Chesbro W, Arbige M, Eifert R (1990) When nutrient limitation places bacteria in the domains of slow growth: metabolic, morphologic and cell cycle behavior. FEMS Microb Ecol 74:103-120

Costerton JW, Lewandowski Z, Caldwell DE, Karber DR, Lappin-Scott HM (1995) Microbial biofilms. Annu Rev Microbiol 49:711-745

Dobbs FC, Guckert JB (1988) Callianassa trilobata (Crustacea: Thalassinidae) influences abundance of meiofauna and biomass, composition, and physiological state of microbial communities within its burrow. Mar Ecol Prog Ser 45:69-79

Fenchel $\mathrm{T}$ (1969) The ecology of marine microbenthos. IV Structure and function of the benthic ecosystem, its chemical and physical factors and the microfauna communities with special reference to the ciliated Protozoa. Ophelia 6: $1-182$

Findlay RH, White DC (1983) The effects of feeding by the sand dollar Mellita quinquiesperforata (Leske) on the benthic microbial community. J Exp Mar Biol Ecol 72:25-41

Findlay RH, White DC (1984) In situ determination of metabolic activity in aquatic environments. Microbiol Sci 1:90-95

Findlay RH, Trexler MB, White DC (1990) Response of a benthic microbial community to biotic disturbance. Mar Ecol Prog Ser 62:135-148 
Grant J (1983) The relative magnitude of biological and physical sediment reworking in an intertidal community. J Mar Res 41:673-689

Kaneshiro E, Wyder MA, Wu Y, Cushion MT (1993) Reliability of calcein acetoxy methyl ester and ethidium homodimer or propidium iodide for viability assessment of microbes. J Microbiol Methods 17:1-16

Kaprelyants AS, Gottschal JC, Kell DB (1993) Dormancy in nonsporulating bacteria. FEMS Microbiol Rev 104:271-286

Kjelleberg S, Hermansson M, Mårdén P, Jones GW (1987) The transient phase between growth and nongrowth of heterotrophic bacteria, with emphasis on the marine environment. Annu Rev Microbiol 41:25-49

Krantzberg G (1985) The influence of bioturbation on physical, chemical and biological parameters in aquatic environments: a review. Environ Pollut 39:99-122

Kristensen $\mathrm{E}$, Jensen $\mathrm{MH}$, Andersen TK (1985) The impact of polychaete (Nereis virens Sars) burrows on nitrification and nitrate reduction in estuarine sediments. J Exp Mar Biol Ecol 85:75-91

Kristensen E, Jensen MH, Aller RC (1991) Direct measurement of dissolved inorganic nitrogen exchange and denitrification in individual polychaete (Nereis virens) burrows. J Mar Res 49:355-377

Lawrence JR, Wolfaardt GM, Korber DR (1994) Determination of diffusion coefficients in biofilms by confocal laser microscopy. Appl Environ Microbiol 60:1166-1173

Lawrence JR, Korber DR, Wolfaardt GM, Caldwell DE (1997) Analytical imaging and microscopy techniques. In: Hurst CJ, Knudsen GR, McInerney MJ, Stetzenbach LD, Walter MV (eds) Manual of environmental microbiology. ASM Press, Washington, DC, p $29-51$

Lebaron P, Parthuisot N, Catala P (1998) Comparison of blue nucleic acid dyes for flow cytometric enumeration of bacteria in aquatic systems. Appl Environ Microbiol 64: $1725-1730$

Lovell CR, Piceno Y (1994) Purification of DNA from estuarine sediments. J Microbiol Methods 20:161-174

Mangum C, Sassaman C (1969) Temperature sensitivity of active and inactive metabolism in a polychaetous annelid. Comp Biochem Physiol 30:111-116

Marinelli RL, Boudreau BP (1996) An experimental and modeling study of $\mathrm{pH}$ and related solutes in an irrigated anoxic coastal sediment. J Mar Res 54:939-966

Meacham C, Duncan T (1991) MorphoSys. Version 1.29. University Herbarium, Univerisity of California, Berkeley, CA

Myers AC (1972) Tube-worm-sediment relationships of Diopatra cuprea (Polychaeta: Onuphidae). Mar Biol 17:350-356

Editorial responsibility: Otto Kinne (Editor).

Oldendorf/Luhe, Germany
Norland S (1993) The relationship between biomass and volume of bacteria. In: Kemp PF, Sherr BF, Sherr EB, Cole JJ (eds) Handbook of methods in aquatic microbial ecology. Lewis Publishers, Boca Raton, FL, p 303-307

Novitsky JA (1983) Heterotrophic activity throughout a vertical profile of seawater and sediment in Halifax Harbor, Canada. Appl Environ Microbiol 45:1753-1760

Novitsky JA, Karl DM (1986) Characterization of microbial activity in the surface layers of a coastal sub-tropical sediment. Mar Ecol Prog Ser 28:49-55

Paerl HW, Pinckney JL (1996) A mini-review of microbial consortia: their roles in aquatic production and biogeochemical cycling. Microb Ecol 31:225-247

Revsbech NP, Jorgensen BB (1986) Microelectrodes: their use in microbial ecology. Adv Microb Ecol 9:293-352

Roth BL, Poot M, Yue ST, Millard PJ (1997) Bacterial viability and antibiotic susceptibility testing with SYTOX Green nucleic acid stain. Appl Environ Microbiol 63: 2421-2431

SAS Institute Inc (1997) SAS/STAT ${ }^{0}$ software: changes and enhancements through release 6.12 . SAS Institute Inc Cary, $\mathrm{NC}$

Steward CC, Nold SC, Ringelberg DB, White DC, Lovell CR (1996) Microbial biomass and community structures in the burrows of bromophenol producing and non-producing marine worms and surrounding sediments. Mar Ecol Prog Ser 133:149-165

Stewart PS, Peyton BM, Drury WJ, Murga R (1993) Quantitative observations of heterogeneities in Pseudomonas aeruginosa biofilms. Appl Environ Microbiol 59:327-329

Stoodley P, deBeer D, Lewandowski Z (1994) Liquid flow in biofilm systems. Appl Environ Microbiol 60:2711-2716

Troussellier M. Courties C, Zettelmaier S (1995) Flow cytometric analysis of coastal lagoon bacterioplankton and picophytoplankton: fixation and storage effects. Estuar Coast Shelf Sci 40:621-633

Turley CM, Hughes DJ (1992) Effects of storage on direct estimates of bacterial numbers of preserved seawater samples. Deep-Sea Res 39:375-394

Wolfaardt GM, Lawrence JR, Robarts RD, Caldwell SJ, Caldwell DE (1994) Multicellular organization in a degradative biofilm community. Appl Environ Microbiol 60: $434-446$

Yingst JY, Rhoads DC (1980) The role of bioturbation in the enhancement of bacterial growth rates in marine sediments. In: Tenore $\mathrm{KR}$, Coull $\mathrm{BC}$ (eds) Marine benthic dynamics. Univ South Carolina Press. Columbia, SC, p $407-421$

Submitted: September 4, 1998; Accepted: January 17, 1999 Proofs received from author(s): June 4, 1999 